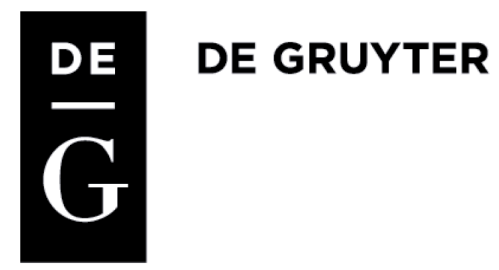

\title{
FINANCIAL CRIME AMONG POLISH WORKERS IN THE YEARS 1945-1956
}

The subject of this article is financial crime among workers, in particular industrial workers who were supposed to be the "vanguards" of the new political system created in Poland after the year 1944. The paper will concentrate on theft in industrial plants and its motivations. This text also discusses the speed with which these negative - both for the economy and the Polish society - phenomena were shaped in the times when the experience of occupation and the new political experiences created unique circumstances their emergence.

Keywords: Poland, financial crime, working class.

doi:10.1515/sho-2016-0006

\section{INTRODUCTION}

When an American historian Padraic Kenney analyzed the intensity of abnormal behaviors in the Polish working class circles after the war, he referred to the concept of the so-called moral economy [Kenney P. 2015: 24, 110]. Edward Palmer Thomson, the English political scientist and activist who coined the phrase, studied social protests in England in the $18^{\text {th }}$ century and the birth of the working class at the time. He posed a thesis that when basic material conditions of the community are violated, this community resorts to hostile (yet not violent) acts towards those who are blamed for creating the crisis [Thomson P. E. 1991: 185-258]. The essence of moral economy entails just distribution of goods, which satisfies the basic material needs of the poor. Breaching this rudimentary rule justifies resorting to illegal, even criminal actions, and makes the community see such actions as ethically justified [Buszko A. 2015: 438-439]. 
This is one of the contexts in which the scale of abnormal behaviors in Polish industrial plants after the war can be considered [Chumiński J. 2015]. Contrary to what the authorities had expected, negative behaviors in factories and other workplaces appeared almost immediately. As early as June 1945, the writer Rudolf Lessel published an article in a socialist magazine "Robotnik" [Worker] entitled "Sound the alarms!" in which he compared the efficiency of Polish workers before and after the Second World War. He wrote:

Before 1939, Polish workers worked more efficiently for capitalist entrepreneurs, and they even claimed that they worked better than foreign workers [Lessel R. 1945: 4142].

This attitude to professional responsibilities was no longer manifested after the war. The author noticed:

[...] one can look back on our pre-war production and see a promise of what should be happening in our industry right now. One could expect that workers in democratic Poland, working to rebuild the country that they co-own, will double or multiply the intensity of their work, in order to accelerate this reconstruction and thus to improve their own lives and those of their brothers, their fellow citizens. Unfortunately, this optimism would not be justified. Polish workers are now working badly [Lessel R. 1945: 41-42].

This opinion is hardly surprising considering the fact that productivity in the mining industry was only $27 \%$ of what it had been before the war, and in the textile industry $-16 \%$. Between 8 and $20 \%$ of staff were regularly absent from work, unpunctuality was prevalent, as were the so-called "odd jobs" and, most importantly, the number of thefts of company goods soared to an unprecedented scale [Lessel R. 1945: 41-42].

These behaviors were in sharp contrast with what people (also from abroad) thought about Polish workers before the war. Halina Krahelska was a work inspector and knew the reality of plants, therefore her assessment is worth mentioning:

There are some features in Poles which make Polish workers excellent (...). They are clever, determined, independent and they know how to concentrate their will and efforts on the task assigned [Krahelska H. 1934: 12].

This opinion corresponds with the assessment of Henry Ford, who emphasized unusual innovativeness of Polish workers employed in his factories, or with remarks of Max Weber on the ability of Polish female workers 
to "change their entire nature" once they had to face new economic conditions [Ford H. 1924: 93; Weber M. 1994: 27].

\section{THEFT IN INDUSTRIAL PLANTS}

Right from the beginning of the so-called state-controlled economy, one of its most harmful and most demoralizing nuisances were thefts, committed by workers on a massive scale. It is hard to precisely determine the scale of the phenomenon, as the cases we know of were only the tip of the iceberg. As early as 1945, though, according to the opinions of plant managers, approximately 10 to $30 \%$ of the output was stolen [Kenney P. 2015: 111; Zawisza M. 2015: 212]. This dirty business was particularly common in plants producing consumer goods, i.e. in the textile, clothing, food, tobacco and leather sectors - wherever it was possible to easily re-sell the goods on the black market. In some regions, unemployed workers even demanded to work in those plants and refused to work in plants where it was more difficult to steal e.g. in the metal industry. According to the authorities, supply of stolen goods in the first months after the war even led to a decrease in black market prices. In the factories which did not manufacture consumer goods, tools, light bulbs, wood, sanitary equipment, and other products which could be sold or used at home were stolen. All that destabilized the economic situation of the plants [Zawisza M. 2015: 215-216].

It must be emphasized that before the war, thefts were very infrequent and even at the peak they did not exceed $2 \%$ of the output. The scale of the problem after the war was due, according to the observers back then, not only to general social demoralization, but most importantly to the difficult financial situation of workers. Workers openly admitted that:

[...] they are forced to steal because quotas of basic products received by workers and their children and parents incapable of work are very low, and because of low wages they cannot afford to buy these expensive products on the free market [AAN (Archive of New Files), CKW PPS, (Polish Socialist Party Central Executive Committee), 235/ VII/169, f. 20].

As we can see, thefts were the alternative to penury. As the author of the article published in November 1946 observed, with wages 2 or 3 times lower than the subsistence level, those who did not steal very often suffered from hunger, lived in unheated houses and walked in worn out 
shoes ["Słowo Polskie", issue 17, November 17, 1946]. In July 1948, the Department of Economy of the Polish Socialist Party Regional Committee pointed to the direct relationship between low wages and the intensity of the problem. A staggering $63 \%$ of urban workers worked for less than the subsistence level. The results were as follows:

Female workers make extra money by cleaning and doing laundry, male workers by unloading coal etc., but there are few people who make extra money this way. The majority makes extra money by stealing. If we consider theft from the financial point of view, it causes a double loss: it diminishes the state income by the full value of the material stolen, but it improves the worker's budget only by a fraction of this value, while the rest of it goes to unjust private initiative [AAN, CKW PPS, 235/XV/43, ff 167-168].

Sometimes thefts were peculiarly justified by workers, who often claimed that "even if you don't steal, even if you don't drink, you are sent to Russia anyway" [AAN, KC PPR (Polish Workers' Party Central Committee), 295/ IX/227, f. 47; AAN, KC PPR, sign. 295/VII/267, f. 2]. The element of class justice was also present in the justifications of theft, as one of the workers said:

[...] we are fired for the smallest mistake, while the Directors who commit the biggest frauds are transferred to other positions without any consequences [Kenney P. 2015: $111]$.

In their attempt to limit this procedure, the authorities administered heavy punishments. At first they applied regulations carried over from before the war, which made no distinction between crime against private and collective property. It is also worth noting that the Criminal Code adopted on July 11, 1932, stipulated in section 257 (2) that in the case of crime against goods "of smaller value, the court can adopt extraordinary mitigation of the penalty, and if the criminal stole an object of small value, out of poverty, to satisfy their basic needs, the court can even waive the penalty". This was also included in the presidential regulation of July 11, 1932 [Journal of Laws no. 60, item 571].

After the war, the authorities came to the conclusion that crimes against collective property should be punished more heavily than those against private property. As early as November 1945, the decree of November 16, 1945 on "Crimes posing a special threat in the period of state reconstruction" included a whole chapter devoted to crimes against the economic interest of the state [Journal of Laws, no. 53, item 300] (nearly all of its pro- 
visions were then included in the so-called small criminal code adopted on June 13, 1946) [Journal of Laws, no. 30, item 192]. The decree was complemented with two acts (also of November 16, 1945) on the creation of a Special Commission for fighting with fraud and economic abuse, and on the emergency procedure. The former act stipulated that the Commission is established to:

[...] detect and investigate crimes against the interest of the economic or social life of the country and in particular: appropriation, theft of collective goods or theft of publicly administered goods [Journal of Laws, no. 53, item 302].

The Commission had a lot of authority. In the form of an administrative decision, it could sentence a suspect to up to 2 years in a work camp [Journal of Laws, no. 53, item 302]. The latter decree introduced the emergency trial procedure for thieves or those guilty of appropriation:

[...] to the harm of the state, local government, public law institutions, a state- or localgovernment-owned company or one under state or local government administration, or a national social institution [Journal of Laws, no. 53, item 301].

New legal regulations we accompanied with heavier penalties. Standard disciplinary punishments used by plant administration such as fines, reprimands, forced unpaid leave or dismissal, were combined with publicized court trials in which long imprisonment penalties were administered. There were even cases where the death penalty was administered (e.g. for stealing leather conveyor belts; although it is unknown whether these sentences were enforced, 10-year prison sentences for stealing conveyor belts were not uncommon) [Chumiński J. 1999: 139; AAN, KC PPR (Polish Worker's Party Central Committee), 295/XI/325, ff 8-9; AIPN (The Archive of the Institute of National Remembrance), MBP GM (Minister's Office of the Ministry of Public Security), 41/462a; AIPN MBP GM, 38/1a]. In general though, the effectiveness of those actions was quite limited. A kind of a solidarity existed between thieves. There were even instances of strikes to defend those caught stealing, whom the economic administration wanted to punish with dismissal. Plant supervisors who were too diligent in performing their tasks were often beaten up and injured, as workers deliberately hid sharp objects in their pockets, they also had bottles and other things thrown at them [Zawisza M. 2015: 217]. The limited efficiency in the fight against theft was also due to a specific form of cooperation between thieves and plant administration. This was one of the 
reasons why fighting with this problem was so unsuccessful. The extended supervision system in place did not work, because even factory guards were involved in organized stealing networks.

In the late 1940s, crimes against collective goods were one of the most frequent, and their number kept growing (in 1949, 23,592 people were sentenced, which made up $15.7 \%$ of the total number of convictions). Notably, most thefts occurred in big industrial centers, in particular those manufacturing consumer goods, e.g. in Łódź. It was noted that:

[...] the particular intensity of crimes against property is emphasized even more by the indicator of thefts per 10,000 inhabitants - here it equals 35, while the national is 9.8. The concentration of the textile industry in Łódź allows us to assume that the largest intensity of crime against collective goods is found in this particular branch of the economy [Zawisza M. 2015: 56].

The problem of large-scale thefts in the textile industry was a lasting one, and it was the subject of the debate in the Political Bureau. In May 1955, the Bureau came to the conclusion that:

Insufficient protection of collective property and continued occurrence of theft, especially in the wool, knitting and hosiery industry plants, remain a significant problem [AAN, KC PPR, 1662, ff 47-48].

This is the context in which the radical escalation of heavy penalties for these crimes has to be considered. The tendency for totalitarianization of social life and copying the Soviet solutions was also an important driver. This transformation was manifested by two decrees of March 4, 1953 on increasing protection of collective property and on protecting collective property against petty theft [Journal of Laws, no. 17, item 68, no. 17, item 69]. Their issuance was explained by the adoption of the constitution of July 1952, wherein article 77 included the following provisions:

Every Polish citizen is obliged to protect collective property and strengthen it as a firm foundation of the state's development and a source of wealth and power for the Homeland. Those who try to sabotage, commit diversion, harm or attack collective property are to be punished with utmost severity [Journal of Laws, no. 33, item 232].

In fact, these acts copied the Soviet act of 1932 on protecting the property of state plants, collective farms and cooperatives, and were characterized by extraordinary severity [Zawłocki R. (ed.) 2015: 13]. Even the smallest offenses were heavily punished. The first decree introduced a penalty 
of up to 5-year imprisonment in cases of appropriation of collective property worth as little as over 300 PLN (which was approximately $50 \%$ of the minimum wage). What is also important, in those cases, pre-trial detention was required. Furthermore, the suspension of the penalty was not an option. Penalties for smaller thefts (below 300 PLN) were regulated by the second decree. It stipulated that:

Every offense against collective property, its integrity and immunity, even the smallest one, has to be severely punished and condemned by the society [Journals of Laws, no. 17, item 69].

In that case, the least serious thefts were punished with 6- to 12-month imprisonment. Such cases were expected to be examined within 14 days, and as it was pointed out, except in extraordinary circumstances, there should be no suspension of the punishment. In fact, even the smallest thefts, those of just a few pennies, were punished with 6 months in prison, without the option of suspending the sentence. These regulations were a clear departure from the provisions of the code of 1932, which stipulated that a criminal who has committed the crime out of poverty can even be spared the punishment.

New regulations caused a rapid increase in the number of convictions. It is enough to say that in the years 1949-1952 there were 95,506 convictions, and in 1954 and 1955 - 100,523 (in 1954 there were 49,263 sentences for these crimes, which comprised $26 \%$ of all convictions, and in 1955 51,260, accounting for 24.7\%) [RS (Statistical Yearbook) 1956: 389; AAN, MS (Ministry of Justice), 91, f. 26]..$^{1}$ It is worth noting that as a result of these decrees, workers ended up in prison even for the smallest offenses. For example, it is hard to justify 8-month imprisonment for a woman who had drank milk worth 0.5 PLN, arresting a "multiple-time work leader" from Stalowa Wola Foundry for taking home a canvas apron (he explained that it was too big and wanted to take it in), or arresting "a model oil mine foreman" for appropriating small glass panes which had been laying in the trash for two months. One truly bizarre case was suing a 9-yearold boy who was accused of: "receiving candy from a friend, although

${ }^{1}$ Different information can be found in a report drafted by the Ministry of Justice. Based on the decree on increasing collective property protection, in 1954 there were 15,019 sentences, and based on the decree on protecting collective property against petty thefts 33,692; in the year 1955, there were 20,794 and 33,567 sentences, respectively. 
he had grounds to believe that it had been acquired illegally" [AIPN, BU (Information Provision Bureau), 1572/10, ff 288-289].

Also, extensive militarization of industrial plants took place in the early 1950s. The security system of industrial guards was developed. Sometimes the guards were extremely brutal. In one textile plant in Łódź, in July 1952, a worker suspected of stealing yarn was shot during revision (and this was not an isolated case). This case became political in nature when "the factory staff collected money for a wreath, on which they intended to write »For a dearly beloved colleague«" This caused an intervention from the Protection Office, which forced the staff to withdraw from including the phrase [AIPN, BU, 1572/1447, f. 134].

These repressions were of course just a small part in the process of totalitarianization of social life and penalization of even the smallest offenses. It is enough to say that as a result of the Act of April 1950 on "Protecting socialist work discipline", around 800,000 cases were brought to courts, and 30,000 people ended up in prisons [Chumiński J. 1999: 28-52]. The act was accompanied by other legal acts which in fact introduced militarization of work. One example was the Act of March 7, 1950 which deprived some categories of workers in important professions or specialties of the right to change employment for two years. People who would breach this feudal-like law, which confined them to a given plant, could be punished with up to 6-month imprisonment and a fine up to 250,000 PLN [Journal of Laws, no. 10, item 107]. Graduates of vocational high schools and colleges had limited options of choosing where to work, due to the so-called "work order" which remained in force for 3 years. A person evading work or quitting the assigned post faced up to 3-month imprisonment and a fine up to 100,000 PLN. Also plant managers employing a person bound by a work order without permission could face up to 6 moth in prison and a fine up to 250,000 PLN [Journal of Laws, no. 10, item 106]. A decree of March 4, 1953 on intensifying the fight against low quality in production (a copy of Soviet legislation) was even more bizarre. It stipulated 5 years in prison for plant managers, production department managers and technical control staff for releasing goods that did not meet the required quality standards. If the goods were used for military purposes or exported, the penalty was between 2 and 10 years in prison [Journal of Laws of socialist Poland, no. 16, item 63].

In this context, the ruthless treatment of people accused of even the smallest offenses is hardly surprising. In 1949, the Special Commission sentenced 9,134 people to work camps, even including, as the prison doctor 
alarmed, severely sick people and amputees (e.g. a man after a severe heart attack was transported to the camp on a stretcher, another one suffered from asthma and was unable to work, a prisoner with advanced diabetes and a heart condition died in the camp, etc.) [AAN, KSdWzNiSzG (Special Commission on Fighting with Fraud and Economic Abuse, 18, ff 202-205; 17, f. 66]. This obstinacy was all-encompassing; its victims included e.g.: a woman with a suckling infant, sentenced to 8 months in prison for criticizing the rationing of deficit goods in a shop, a disabled woman who had lost three sons in war, arrested for sabotaging compulsory supplies; a demented elderly man who required round the clock care; and a 12-year old girl who distributed anti-government leaflets [Chumiński J. 1999: 321].

Small changes limiting the repressive law were introduced in late 1954. This resulted from the general liberalization of the communist system following Stalin's death. In a decree issued in December, the mandatory minimum sentence of 6-month imprisonment for stealing goods of small value was abolished, as well as section 6, which banned suspending sentences. In the decree on increasing protection of collective goods, the minimum punishment of one year was also abolished, and conditional suspension of the punishment was allowed in special circumstances [Journal of Law, no. 57, item 283]. These changes were reflected in the decrease in the number of trials for crimes against collective property - in 1956, 32,619 people were convicted, and in 1957 - 42,902 [Statistical Yearbook, 1958: 467].

\section{WHY WAS COLLECTIVE PROPERTY STOLEN?}

The answer to questions regarding the reasons behind these abnormal phenomena in the socialist economy requires considering both systemic factors and those resulting from the negative changes in the postwar composition of the working class. In the former aspect, the choice of the industrialization model adopted by the communist states was of key importance. It was based on extensive use of cheap and poorly qualified workforce. However, this involved a deviation from the $19^{\text {th }}$ and $20^{\text {th }}$ century evolution of working class. Ralf Dahrendorf noted that until the $19^{\text {th }}$ century, workers' qualifications tended to worsen, and unqualified workers became a clearly dominating group. They were recruited among peasantry, women, adolescents and, in some countries, immigrants. The role of craftsmen and qualified workers decreased. These trends were relat- 
ed to the specific nature of industrialization processes, based on a narrow division of work and on the heavy industry. In the $20^{\text {th }}$ century, especially from the 1930s onwards, an opposite trend emerged. The role of qualified workers grew, and the category of semi-qualified workers appeared, while the role of unqualified workers was gradually limited. This was related to technical innovations and the new philosophy of industrial organization [Widerszpil S. 1965: 87; Dahrendorf R. 2008: 52-55]. Countries of the Eastern block, which after the Second World War copied the Soviet model of industrialization, in fact still rooted in the $19^{\text {th }}$-century, began a return to the labor model corresponding to that stage of development namely, the one in which unqualified and poorly paid physical workers dominated in the industry [Chumiński J. 1999: 53-54].

The radical increase in employment in industry, disproportionate to other sectors of the economy, reflected this trend in Poland (Graph 1). It is enough to point out that as early as 1946, employment in industry was 36\% higher than in 1937 (10767.9 thousand and 788.3 thousand respectively), in 1949 it was 94\% higher (15301.7 thousand), and in 1955 - 185\% higher (2246.6 thousand). [SP (Statistics in the Industry) 1956: 11]. According to the National Committee of Economic Planning in the year 1946 the employment outside agriculture in the whole national economy was equal to $76.3 \%$ of the 1937 number (in 1937, it was 4233 thousand, while in $1946-3,230$ thousand), and only exceeded that value by $3.6 \%$ as late as 1949 (4,385.5 thousand) [AAN, PKPG (National Committee of Economic Planning), 683, f. 69]. It is very hard to define the scale of over-employment in the Polish industry at the end of Six-Year Plan. Likely, though, if we assumed pre-war work efficiency, a large part of the employment increase which occurred in the years 1950-1955 could be eliminated without any loss for the production volume. One should remember that in 1950, the pre-war volume of production was achieved (within new borders), but the employment was higher, by over 500 thousand workers, than before the war. The results of a 1953 study by the Economic Sciences Workshop of the Polish Academy of Sciences concerning the estimates of the efficiency increase margin in large and medium factories (excluding the mining industry) are quite telling. The study included plants employing a total of 309,000 workers and accounting for approximately $20 \%$ of the total production. It concluded that the employment margin in the whole industry (if the efficiency level of the best plant in the sector was the average) comprised 615,000 people, i.e. over $80 \%$ of the employment increase in industry which occurred between 1949 and 1953. Even if we consider the average ef- 
Graph 1. The number of industrial workers in the years 1937-1955

(in thousands)

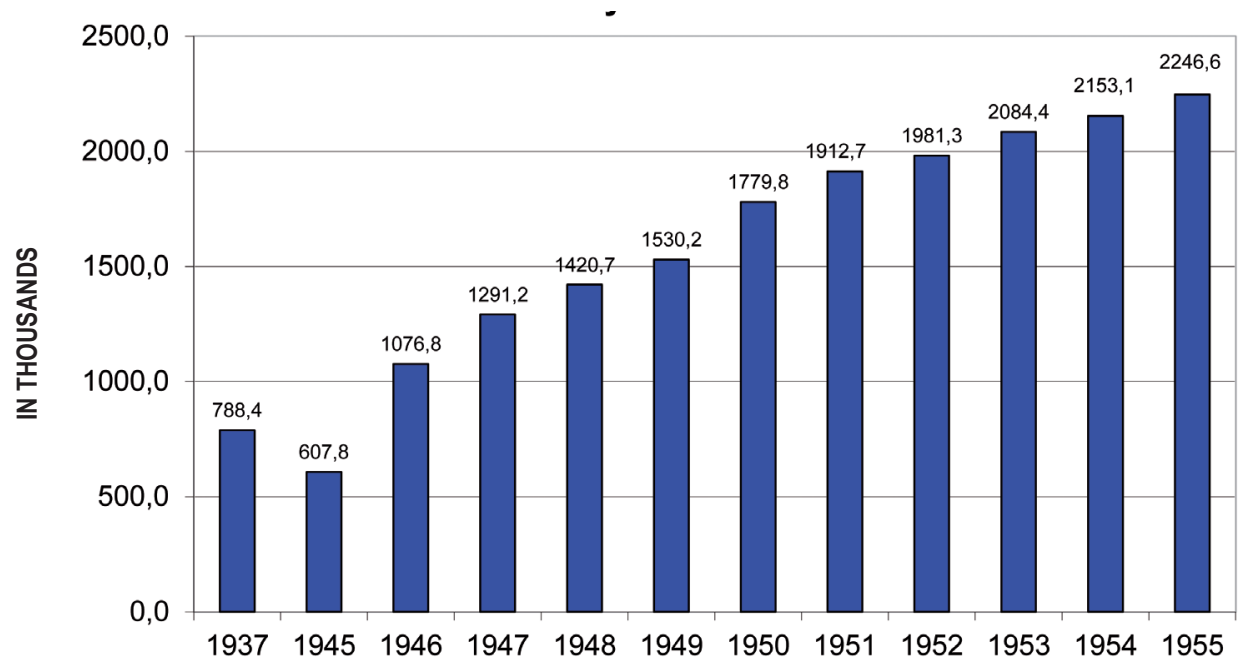

Source: Statystyka przemystu 1945-1955, [Industry statistics 1945-1955], GUS, Warsaw 1956: 11.

ficiency level in individual sectors, the employment margin still comprised 400,000 people [AAN, PKPG, 3330, ff 17-27; Karpiński A. 1958: 63]. ${ }^{2}$

In the first decade of the socialist economy, a condition called "unemployment at work" (phrase coined by Janos Kornai) was shaped. Excessive employment, which was the result of the industrialization model adopted, created many problems, e.g. lower work discipline, decreased quality, less diligent workers, or increased rotation in the workforce. It also limited the options for improving qualifications and did not force technology modernization or work organization improvement [Kornai J. 1985: 346347; Karpiński A. 1989: 129-132]. From the point of view of our analysis, the most important result was preventing workers from improving their financial situation and, as a result, lowering consumption and employing thousands of people from other social groups, often demoralized and with minimum qualifications for work in the industry.

This is the context in which the pauperization of the working environment (even if we compare quality of life with the pre-war period) has to be considered. At the end of Six-Year Plan, the actual salary level from 1938

2 According to different estimates, the number of workers in the whole national economy who were employed within the Six-Year Plan increased by 2,232,000, out of which 500,000 , i.e. almost $25 \%$, was excessive employment. 
Graph 2. Estimated wages of workers in the years 1938 and 1955

(in PLN from 1955)

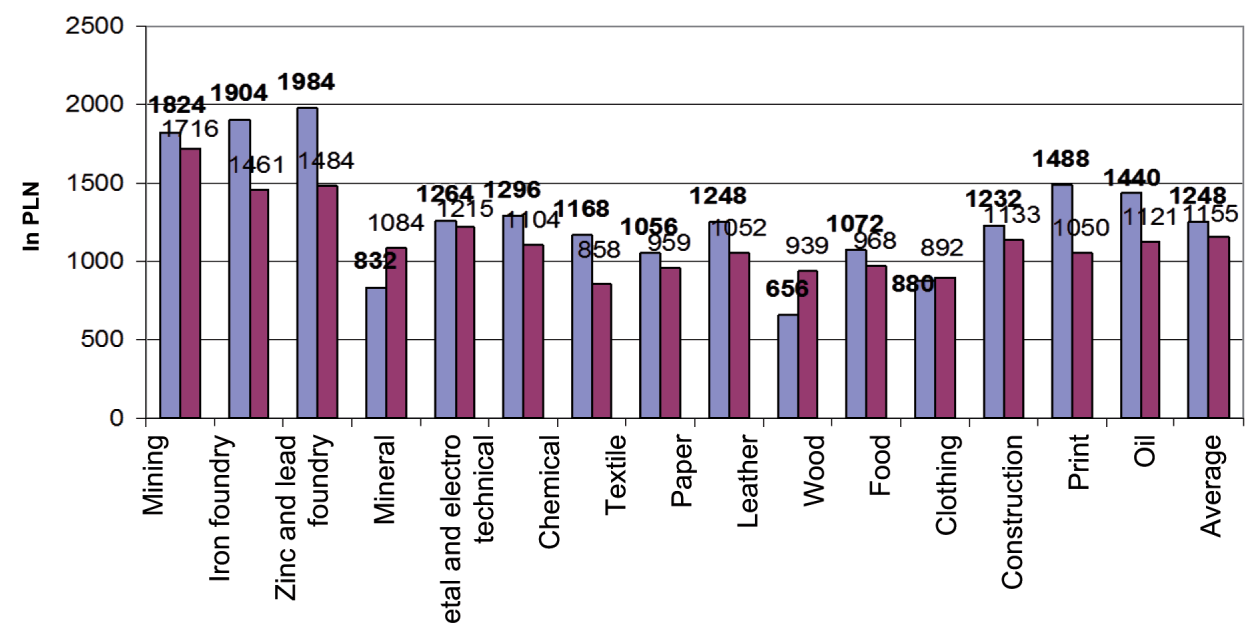

The estimates of wages in particular branches and sectors of the industry in 1938, calculated into PLN from 1955 were set assuming the indicator of the increase in the cost of living calculated by the Polish Statistical Office (GUS) for the year $1954=8$ (with pre-war wages=1)

Source: Own work Compare: Mały rocznik statystyczny 1939 [Short statistical yearbook 1939], GUS, Warszawa 1939 r.: 274; Rocznik statystyczny 1958 [Statistical Yearbook 1958], GUS, Warszawa 1958: 93-95; AAN, PKPG sign. 312, Porównanie dochodów na głowę ludności pracowniczej w 1954 i 1937 r. [Comparison of incomes per capita among the working class for the years 1954 and 1937]: 3-5.

had not been achieved - on average, salaries amounted to $93 \%$ of that value, and in some important industry sectors earnings were even lower (e.g. in the steel industry they were $77 \%$ of pre-war wages, in textile $-73 \%$, in chemical - 85\%, in printing - 71\%) (Graph 2). The so-called "cheap work" was a permanent problem in the so-called real socialism. The fact that remunerations accounted for just a little over $10 \%$ of the production cost of the national industry throughout the whole period of socialist Poland is also telling. In 1954, this was $11.2 \%$, and in the 1980s - 10.7\% (data for 1988). It is worth emphasizing that in the years 1918-1939, remunerations accounted for over $20 \%$ of the value of goods produced (data for the year 1937) [TS (Statistical tables) for the year 1956, ff 126-127; GUS (Polish Central Statistical Office) 1989: 12-13; MRS (Short statistical yearbook) 1939: 134]. As a consequence, there appeared a specific "vicious circle" resulting from excessive employment. The mechanism was described by Józef Bobek:

[...] the doctrine of full employment, abolishing the efficiency requirement, is in itself a factor reducing efficiency. Low efficiency level entails a proportionally reduced national income [Bobek J. 1988: 80]. 
And the "proportionally lower income" equaled low wages. It is not surprising that the lack of a system promoting good work entailed all the negative consequences in the Polish industry, which were described in the early 20th century by M. Weber:

From a purely economic point of view, the concept of low wages (...) fails in every setting where goods production requires qualified workers, working on expensive and easily damaged machines, and overall careful work and initiative. In such conditions low wages do not pay off and are counter-effective [Weber M. 1994: 43].

The reality of the Polish economy in the 1940s and 1950s (but also later) is almost a model illustration of the predictions of the German scholar. Widespread botchery, low work discipline and low production quality resulted in multi-billion losses. Additionally, low wages made theft a justified way for workers to achieve bearable living conditions.

The third factor affecting the scale of collective property theft in industrial plants was the demoralization of the working class, resulting from the six years of occupation and the clear deterioration of working class composition compared to the pre-war period. Many observers of social and economic life of the time pointed to this aspect. One notable example is Kazimierz Wyka, who wrote an excellent book entitled "Życie na niby. Pamiętnik po klęsce" [Fake life. Life after the defeat] in which he described the consequence of work alienation in the occupation period [Wyka K. 1984]. The development of black market, sabotaging the occupier's economy, and the demoralization that developed at the time left its mark on work discipline and work ethics after the war. This concerned in particular those who entered their professional lives in the conditions of the occupier's terror and the exploitative war economy. Notably, as early as 1945, a publicist from the "Przegląd Socjalistyczny" [Socialist review] magazine, Kazimierz Dorosz, concluded that the heritage of war was "a cult of force over the law, and the prevalent method of proceeding was accepting any dishonesty as long as it was a means towards an end" [Dorosz K. 1945: 12-13; Jakowicki P. 1948: 4; TZ 1945: 9]. Interestingly, even in the 1990s some Polish intellectuals saw the times of occupation during the Second World War as the origin of social demoralization. A famous writer, Kazimierz Brandys, said in an interview:

[...] the occupation created a new type of a human being and a new social system. A mass of people, millions of anonymous people without a specific view of the world appeared, not associated in any organizations or parties, involved in illegal trade and cheating the authorities - occupational authorities of the time, that is. This is the mass that stayed with us until today [Gardawski J. 1996: 51]. 
After the war, it was very often pointed out that theft was primarily committed by the workers recruited after 1945. One document stated:

A new element has recently entered the plants (...) People from various environments came, bringing their old habits to the plants, their way of thinking unknown to the working class, which is primarily about taking as much as possible from the state and society, and giving as little as possible in return [Kenney P. 2015: 112].

What is also interesting, members of the Polish Workers' Party were accused of having a special inclination to stealing. This is not surprising though, if we consider the sort of protection that they enjoyed on the one hand, and the fact that they belonged to the weakest part of the working class (considering the social and demographic features), on the other.

Also the Ministry of Justice pointed to the fact that the increase in crime against collective property was, on the one hand, caused by the "difficulties in supplying people with basic goods, which caused the appropriation of collective property for speculation in the »black market «". On the other hand, it was pointed that thefts were the result of the "increased influx of new workers to state and cooperative plants", and that these new workers:

[...] had insufficient social awareness and showed an incorrect attitude towards collective property [AAN, MS, 2713, f. 54].

What is also interesting is the fact that the most critical assessments concerned young workers who entered their professional life in socialism. The "specialty" of those young people, "entering the path of independent life" were, as a ministerial study put it:

[...] offenses resulting from the lack of work discipline, lack of respect for property, in particular collective property. and lack of respect for the rules of socialist coexistence (rowdiness) [AAN, MS, 2713, f. 54].

To verify the hypothesis on the deteriorated composition of the working class circles after the war, we will use multidimensional statistical analysis, using the linear ordering method, which allows to put together various specific problems (such as education level, work experience, place of birth, family situation, age structure etc.) and present them in a synthetic form [Morrison F. D. 1990]. ${ }^{3}$ Of course the factors established have

${ }^{3}$ When analyzing differences between individual categories of workers, we distinguished 8 characteristics that could possibly affect their behavior or be a reflection of their 
to be treated carefully, as it is difficult to precisely determine a qualitative difference using quantitative factors (Table 1). It is worth emphasizing, though, that the data obtained confirmed our preliminary assumptions. The standard for workers employed in factories before 1939 was 0.93 (0.81 for women, 0.97 for men), and 0.81 in the case of workers employed in other sectors of the economy ( 0.81 for both men and women). In the case of workers who started work after the war, the standard is much lower: 0.58 (0.59 for women, 0.58 for men).

\section{CONCLUSIONS}

In his work from 1776, "An Inquiry into the Nature and Causes of the Wealth of Nations", Adam Smith stated:

The wages of labour are the encouragement of industry, which, like every other human quality, improves in proportion to the encouragement it receives. A plentiful subsistence increases the bodily strength of the labourer, and the comfortable hope of bettering his condition, and of ending his days perhaps in ease and plenty, animates him to exert that strength to the utmost. Where wages are high, accordingly, we shall always find the workmen more active, diligent, and expeditious than where they are low [Smith A. 2007: 96].

This fairly obvious truth struggled to reach the minds of those responsible for economic affairs throughout the whole socialist period in Poland. Maintaining over-employment of poorly educated and poorly paid workers was one of the reasons why the Polish economy was so weak until 1989. The pauperization of workers resulted in attempts to compensate for the low wages, that is, in common theft of the so-called collective property. In the social awareness, these actions were justified, and they were not commonly condemned. One might hazard a hypothesis that the authorities could not fulfill the financial expectations of the society, and therefore accepted this way of compensating for low wages [Madej K. 2005: 148]. Apart from the periods of brutality (when financial crimes were punished with death penalties), the authorities demonstrated far-reaching tolerance for petty theft. One can see that the communist system was so ir-

attitudes. The standard used is a weight function of the value of individual factors with relative standardization compared to the model, i.e. the maximum value of a characteristic for each factor. 


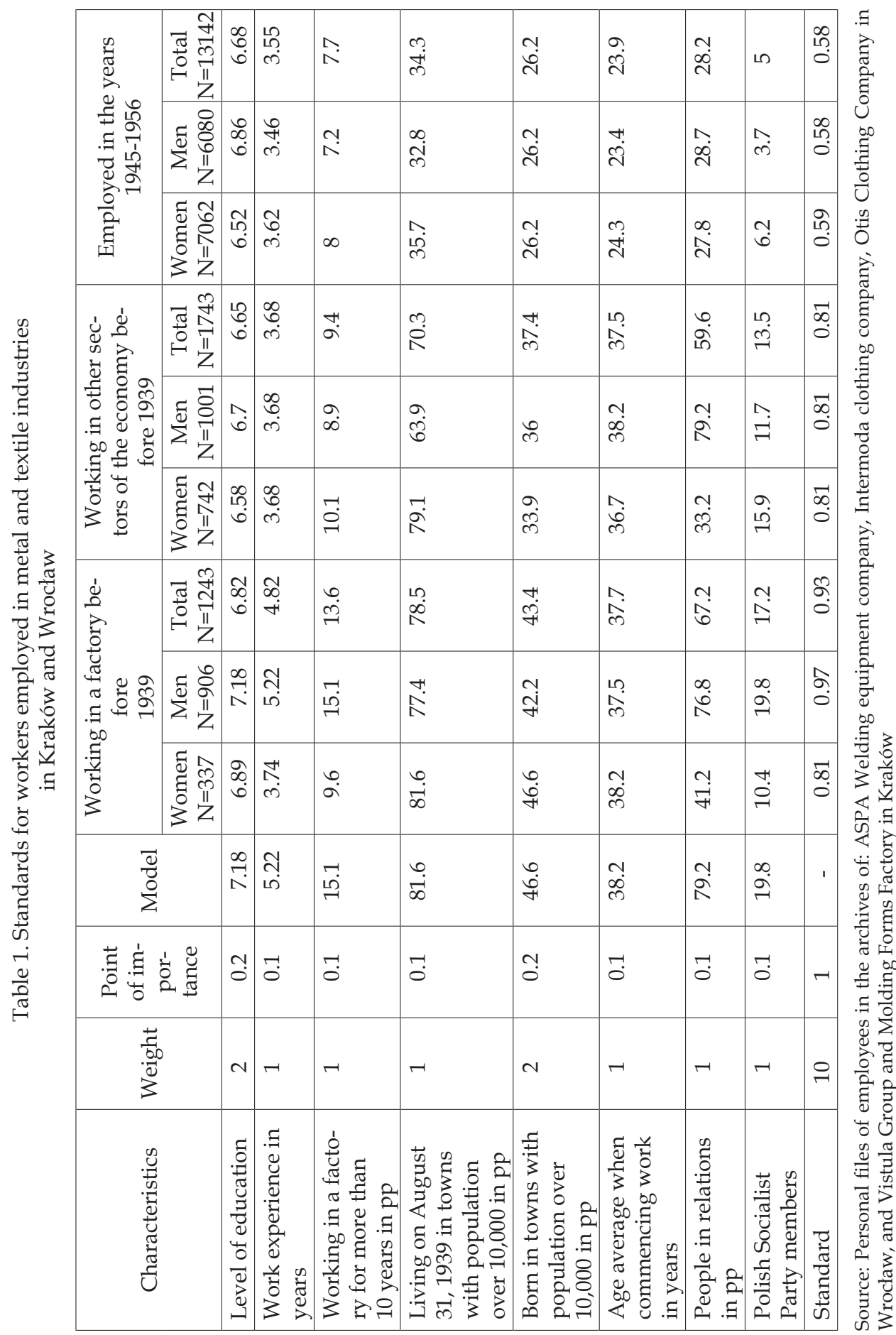


rational that throughout its entire existence in Poland it was incapable of creating an effective mechanism of promoting good work and, on top of everything else, it created a reality in which abnormal work relations were encouraged.

\section{BIBLIOGRAPHY}

\section{ARCHIVE MATERIALS}

Archiwum Akt Nowych (AAN) - Centralny Komitet Wykonawczy Polskiej Partii Socjalistycznej (CKW PPS) [Archive of New files, Polish Socialist Party Central Executive Committee]

AAN - Komisja Specjalna do Walki z Nadużyciami i Szkodnictwem Gospodarczym (KSdWzNiSzG) [Special Commission on Fighting with Fraud and Economic Abuse]

AAN - Komitet Centralny Polskiej Partii Robotniczej (KC PPR) [Central Committee of the Polish United Worker's Party]

AAN - Ministerstwo Sprawiedliwości (MS) [Ministry of Justice]

AAN - Państwowa Komisja Planowania Gospodarczego (PKPG) [National Committee of Economic Planning]

Archiwum Instytutu Pamięci Narodowej (AIPN) - Ministerstwo Bezpieczeństwa Publicznego Gabinet Ministra (MBP GM) [The Archive of the Institute of National Remembrance, Minister's Office of the Ministry of Public Security]

AAN - CKW PPS (Polish Socialist Party Central Executive Committee), sign. 235/VII/169, Report of the Polish Socialist Party Regional Committee in Łódź (1945 r.), f. 20.

AAN - CKW PPS, sign. 235/XV/43, Report of the Economic Department of the Regional Committee in Łódź (July 29, 1948), ff 67-168.

AAN - District Committee of the Polish Worker's Party, sign. 295/IX/227, Report of the Łódź Committee of the Polish Workers' Party for the period between August 1 and September 1, 1946, f. 47.

AAN - Polish Workers' Party Central Committee, sign. 295/VII/267, Excerpt from the Poznań region report for August 1945, f. 2.

AAN - Polish Workers' Party Central Committee, sign. 295/XI/325, A letter concerning mass theft committed in all factories in the textile industry in Łódź (August 22, 1947), ff $8-9$.

The Archive of the Institute of National Remembrance, Minister's Office of the Ministry of Public Security, sign. 41/462a, Information Bulletin 5/27 (February 27, 1948).

The Archive of the Institute of National Remembrance, Minister's Office of the Ministry of Public Security, sign. 38/1a, The report on the activity of the Department IV for July 1947.

AAN - PUWP Central Committee, sign. 1662, Protocol no. 42 from the seating the Political Bureau on May 5, 1955, ff 47-48.

AAN - Ministry of Justice, sign. 91, The report of the Ministry of Justice for the year 1955, f. 26.

The Archive of the Institute of National Remembrance - Information Provision Bureau, sign. 1572/10, National briefing of the Ministry of Public Security (July 7, 1953), ff 288289. 
The Archive of the Institute of National Remembrance - Information Provision Bureau, sign. 1572/1457, Report of Department IV for July 1952, f. 134.

AAN - Special Commission for Fighting with Fraud and Economic Abuse, sign, 18, the Activity of the Special Commission (January-December 1949), ff 202-205.

AAN - Special Commission for Fighting with Fraud and Economic Abuse, sign. 17, The letter from a Milęcin work camp doctor to the Prison Management Department of the Ministry of Public Security (February 5, 1949), f. 66.

AAN - National Committee of Economic Planning, sign. 683, Employment in the national economy excluding agriculture in the years 1946-1954, f. 69.

AAN - National Committee of Economic Planning, sign. 330, The estimate of the margin of work efficiency increase in large and medium industry (1953), ff 17-27.

AAN - Ministry of Justice, sign. 2713, The report of the Ministry of Justice 1946-1952, f. 54

AAN - Ministry of Justice, sign. 2713, The report of the Ministry of Justice 1946-1952, f. 127.

PRESS

„Słowo Polskie”, issue 17 of November 17, 1946.

\section{LITERATURE}

Bobek J. (1988), Próba porównania wskaźników efektywności gospodarki polskiej i wybranych krajów w latach 1970-1985 [An attempt to compare efficiency indicators for the economy of Poland and other selected countries in the years 1970-1985], "Z prac Zakładu Badań Statystyczno-Ekonomicznych GUS" [From the works of the Statistical and Economic Workshop of the Polish Statistical Office, vol. 171.

Buszko A. (2015), Ekonomia moralna a dystrybucja PKB w kontekście szarej strefy [Moral economy and gross domestic product in the context of black market], [in]: Ostaszewski J. [ed.], „O nowy ład finansowy w Polsce. Rekomendacje dla animatorów życia gospodarczego" [New financial order in Poland. Recommendations for the organizers of the economic life], Wydawnictwo SGH, Warsaw.

Chumiński J. (2015), Robotnicy polscy 1945-1956. "Stary" $i$ "nowy" ośrodek przemystowy na przykładzie Krakowa i Wroctawia, [Polish workers 1945-1956. Old and new industrial centers based on the examples of Kraków and Wrocław], Wydawnictwo Uniwersytetu Ekonomicznego we Wrocławiu, Wrocław.

Chumiński J. (1999), Ruch zawodowy w warunkach kształtujacego się systemu totalitarnego 1945-1956 [Professional movement in the conditions of the birth of totalitarian system 1945-1956], Wydawnictwo Akademii Ekonomicznej we Wrocławiu, Wrocław.

Chumiński J. (2012), The Act on Securing the Socialist Discipline of Labour - a contribution to the totalitarianization of social life in Poland, "Studia Historiae Oeconomicae", issue 30.

Chumiński J. (2014), The material situation of polish workers between 1945 and 1956, "Studia Historiae Oeconomicae", issue 32.

Dahrendorf R. (2008), Klasy i konflikt klasowy w społeczeństwie przemystowym [Class and class conflict in the industrial society], Wydawnictwo NOMOS, Kraków 2008.

Decree of November 16, 1945 on crimes posing a special threat in the period of state reconstruction [Journal of Laws, no. 53, item 300].

Decree of November 16, 1945 on emergency procedures, Journal of Laws no. 53 item 301

Decree of November 16, 1945 on the creation and the scope of activity of the Special Commission for Fighting with Fraud and Economic Abuse, Journal of Laws, no. 53, item 302. 
Decree of June 13, 1946 on crimes posing a special threat in the period of state reconstruction [Journal of Laws, no. 30, item 192].

Decree of March 41953 on increasing collective property protection, Journal of Laws, no. 17 , item 68 .

Decree of March 4, 1953 on intensifying the fight against low quality in production, socialist Poland Journal of Laws, no. 16, item 63.

Decree of March 4, 1952 on protecting collective property against petty theft, Journal of Laws, no. 17, item 69.

Decree of December 23, 1954, changing some provisions concerning collective property protection, Journal of Laws, no. 57, item 283.

Dorosz K. (1945), Skrzywdzone pokolenie, [The Harmed Generation] „Przegląd Socjalistyczny" [Socialist Review] issue 1.

Ford H. (1924), My life and work, Wydawnictwo Biblioteka Polska, Warsaw.

Gardawski J. (1996), Przyzwolenie ograniczone. Robotnicy wobec rynku i demokracji, [Limited permission. Workers, market and democracy], PWN, Warsaw.

Jakowicki P. (1948), Złe skutki wojny [Bad consequences of the war], ,"Tygodnik Warszawski” issue 5 (114) of February 1.

Karpiński A. (1958), Zagadnienia socjalistycznej industrializacji Polski [Problems of the socialist industrialization of Poland], Polskie Wydawnictwo Gospodarcze, Warsaw.

Karpiński A. (1980), Zarys rozwoju gospodarczego Polski Ludowej [An outline of the economic development of socialist Poland], Książka i Wiedza, Warsaw.

Kenney P. (2015), Budowanie Polski Ludowej. Robotnicy a komuniści 1945-1950 [Building socialist Poland. Workers and communism 1945-1950], Wydawnictwo WAB, Warsaw.

Polish constitution adopted by the Sejm on July 22, 1952, Journal of Laws no. 33, item 232.

Kornai J. (1985), Niedobór w gospodarce, [Shortage in the economy], PWE, Warsaw.

Koszty produkcji i rentowność w przemyśle uspołecznionym w 1988 r. Production costs and profitability in the state-controlled industry in 1988]. Polish statistical office, Warsaw, 1989.

Krahelska H. (1934), Prawda o stosunkach pracy, [The truth about work], Lwów.

Lessel R. (1945), Bijemy na alarm, [Sound the alarms], "Robotnik" from June 10, 1945; National Industrial Conference, Poznań.

Madej K. (2005), Robotnicy wobec kradzieży mienia społecznego w latach 1956-1970 [Workers and collective goods theft in the years 1956-1970] [in]: Miernik G., Piatkowski S. [ed.], "Robotnicy przemysłowi w realiach PRL", [Industrial workers in socialist Poland], Wydawnictwo Radomskie Towarzystwo Naukowe, Radom-Starachowice.

Short statistical yearbook 1939.

Morrison F. D. (1990), Wielowymiarowa analiza statystyczna [Multidimensional statistical analysis], PWN, Warsaw.

Na alarm!, [Sound the alarm!] “Trybuna Związkowca”, issue 9, August 16-31, 1945.

Statistical yearbook 1956 GUS, Warsaw 1956.

Statistical Yearbook 1958, BUS, 1958.

The regulation of the president of Poland of July 11, 1932, Journal of Laws, no. 60, item 571.

Smith A. (2007), An inquiry into the Nature and Causes of the wealth of Nations, vol. 1, PWN, Warsaw.

Statystyka przemystu 1945-1955, [Industry statistics 1945-1955], GUS, Warsaw 1956.

Statistical tables 1953-1954, GUS, Warsaw 1956.

Thomson E. P. (1991), Customs in Common, Penguin Books, New York.

Act of March 7, 1959 on preventing rotation of workforce in professions and specialties particularly important for state-controlled economy, Journal of Laws, no. 10, item 107.

Act of March 7, 1950 on planned employment of graduates of high schools and colleges, Journal of Laws, no. 10, item 106. 
Weber M. (1994), The Protestant Ethic and the Spirit of Capitalism, Wydawnictwo Test, Lublin.

Widerszpil S. (1965), Skład polskiej klasy robotniczej. Tendencje zmian w okresie industrializacji socjalistycznej, [Composition of the Polish working class. Transformation tendencies in the period of socialist industrialization], PWN, Warsaw.

Wyka K. (1984), Życie na niby. Pamiętnik po klęsce [Fake life. Life after the defeat], Wydawnictwo Literackie, Warsaw.

Zawisz M. (2015), Robotnicy przemystowi w województwie kieleckim w latach 1945-1949 [Industrial workers in the Kielce region in the years 1945-1949], Kielce (unpublished doctoral dissertation).

Zawłocki R. [ed.] (2015), Przestępstwa przeciwko mieniu i gospodarce [Crimes against property and the economy], Wydawnictwo C. H. Beck, Warsaw.

Jędrzej Chumiński - PhD, Professor of Wrocław University of Economics. Head of the Economic History Chair. Scientific interests: social and economic history of Polish People's Republic, social structure, labour relations. 